Jurnal MAKSIPRENEUR, Vol. I, No. 1, 2011, hal. 38-50

\title{
PEARLS: SEPERANGKAT ALAT MONITORING DAN EVALUASI KINERJA KEUANGAN KOPERASI KREDIT
}

\author{
Yuli Kurniyati \\ Fakultas Ekonomi Universitas Proklamasi 45, Yogyakarta
}

\begin{abstract}
PEARLS is a system of 44 financial ratios which the World Council of Credit Unions (WOCCU) employs to provide a detailed picture of credit union operations. Standing for Protection, Effective Financial Structure, Asset Quality, Rates of Return, Liquidity, and Signs of Growth, the PEARLS system was originally designed and implemented with Guatemalan credit unions in the late 1980s. WOCCU now uses it worldwide to monitor the performance of credit unions, to create a universal language that each credit union can speak and understand, to generate comparative credit union rankings, and to provide the framework for a supervisory unit at the second tier. Also, PEARLS presents financial variables upon which credit unions can base their business planning. In essence, PEARLS was designed first as a management tool, and later became an effective supervisory mechanism.
\end{abstract}

Key Words: PEARLS, Monitoring and Evaluation, Financial Performance

\section{LATAR BELAKANG}

Membangun koperasi merupakan suatu proses pembelajaran yang berkelanjutan dan berulang selaras dengan adanya pergantian generasi, pertambahan jumlah anggota masyarakat, dan perkembangan dinamis berbagai aspek kehidupan yang ada dimasyarakat. Selaras dengan perkembangan yang ada maka membangun koperasi tidak bisa menjadi monopoli pemerintah. Telah terjadi suatu perubahan pemahaman bahwa peran Pemerintah sebaiknya tidak bersifat langsung dalam bentuk intervensi penyelenggaraan usaha dan organisasi koperasi. Oleh karena itu pendekatan pemberdayaan masyarakat menjadi prioritas. Dalam hal ini untuk mengembangkan dan menumbuhkan koperasi, organisasi koperasi sendiri yang harus didorong untuk secara aktif membangun dirinya. Hal ini tidak berarti bahwa pemerintah lepas tangan. Pemerintah tetap sangat 
diperlukan untuk menciptakan iklim kondusif yang dibutuhkan, dan mendorong serta menggalang partisipasi positif pihak terkait dalam membangun koperasi. Permasalahannya adalah bahwa pada satu sisi pembangunan koperasi tergantung pada partisipasi aktif berbagai pihak, yaitu terutama dari kalangan koperasi sendiri, yang meliputi anggota, pengurus dan pengelola serta partisipasi aktif pihak terkait baik pemerintah, dunia usaha maupun masyarakat. Pada sisi yang lain belum tentu terdapat pemahaman yang sama tentang tujuan, sasaran dan pengukuran serta kriteria penilaian hasilnya. Hal tersebut potensial mengakibatkan tidak optimalnya dukungan pihak terkait dan tidak terjadi sinergi positif diantara pihak dalam pemberdayaan koperasi. Karena itu perlu dibangun suatu instrumen yang dapat mengukur sejauh mana kemajuan yang diperoleh telah mencapai tujuan dan sasaran yang diharapkan. Alat dimaksud diharapkan akan mempermudah bagi siapapun yang memiliki kepedulian dalam pembangunan koperasi dapat mengetahui kondisi koperasi, mengukur kemajuan yang dicapai dan mengetahui kekurangan yang perlu di sempurnakan atau diatasi. (Prijadi Admadja,2006).

Koperasi sebagai sokoguru perekonomian di Indonesia hendaknya mendapat dukungan pemerintah. Seperti yang diungkapkan Soedjono (2003), bahwa harus ada dukungan yang kuat antara gerakan koperasi dengan pemerintah di segala bidang, baik dalam bidang pengurusan, modal maupun kebijakan. Juga didukung dengan andanya Pernyataan Bersama Konferensi Menteri-menteri Koperasi Se Asia Pasifik di Beijing (1999) dan rekomendasi ILO (organisasai Buruh Internasional) untuk memajukan koperasi (2002) tak lepas dari peran serta pemerintah (Roepke,2003).

Dewan Dunia Koperasi Kredit (World Council of Credit Unions, Inc/ WOCCU) yang berkedudukan di Madison, amerika Serikat ; yang memayungi koperasi-koperasi Kredit (Credit Union) sedunia, telah memperkenalkan sebuah perangkat rasio rasio keuangan yang disebut PEARLS untuk memonitor stabilitas finansial koperasi koperasi Kredit Model (Model Credit Unions) yang dilakukan di Nikaragua,El Salvador, Kenya, Jamaika,Filippina dan Rumania. Credit Union (CU) adalah type khusus dari koperasi kredit yang dikembangkan sejak setengah abad yang lalu di Amerika Utara dan beberapa dekade akhir-akhir ini menyebar ke seluruh dunia, termasuk Indonesia, status hukumnya beragam; ada yang menggunakan badan hukum koperasi (termasuk Indonesia) dan ada pula yang khusus. Dalam tulisan ini sesuai dengan status hukum CU diterjemahkan dengan koperasi kredit. PEARLS disusun menanggapai adanya kekurangan-kekurangan pada sistem CAMEL untuk menilai koperasi-koperasi kredit, khususnya: tidak mengukur pertumbuhan dan tidak menilai secara lengkap struktur keuangan koperasi yang bersangkutan. (Ibnoe Soedjono, 2003). 
Kriteria penilaian yang lebih operasional adalah dengan membandingkan standar yang berlaku pada industri atau jenis usaha koperasi yang sejenis. Pada koperasi idealnya terdapat standar untuk koperasi produksi, koperasi konsumsi, koperasi jasa dan koperasi simpan/pinjam. Untuk koperasi simpan pinjam, Dewan Dunia untuk Kredit Union (WorldCouncil of Credit Union-WOCCU) merekomendasikan penggunaan seperangkat rasio keuangan yang dikenal dengan PEARLS: Protection (perlindungan), Efective Financial Structure (struktur keuangan yang efektif), Asset Quality (kualitas asset), Rate Of Returnand Cost (tingkat pengembalian dan biaya), Liquidity (likuiditas), dan Sign of growth (tandatanda pertumbuhan). PEARLS merupakan rasio keuangan yang telah dikonsolidasikan sedemikian rupa sehingga menjadi program atau alat penilaian atau kriteria penilaian yang mampu mengukur setiap komponen secara terpisah maupun keseluruhan sistem. PEARLS dapat melakukani identifikasi permasalahan yang dihadapi sehingga dapat membantu manajer menemukan solusi yang tepat terhadap kelemahan-kelemahan yang dihadapi.

Tulisan ini berusaha mengupas tentang Apa saja komponen dari PEARLS sebagai alat ukur kinerja keuangan Koperasi kredit dan apa saja tujuan utama dari rasio PEARLS.

\section{KOMPONEN PEARLS SEBAGAI ALAT UKUR KINERJA KOPERASI}

PEARLS adalah sekumpulan rasio keuangan dan indikator-indikator yang memiliki standar baku bagi semua institusi atau lembaga keuangan, atau didefinisikan sebagai suatu sistem monitoring atau pengawasan kinerja lembaga keuangan yang didesain bagi menajemen koperasi simpan pinjam dan lembaga keuangan lainnya. Indikator -indikator PEARLS diukur menggunakan data bulanan, triwulan atau tahunan. Kinerja manajemen koperasi adalah hasil-hasil atau prestasi yang dicapai oleh manajemen koperasi dalam merencanakan, mengorganisasikan, melaksanakan dan melakukan pengawasan terhadap kegiatan koperasi selama kurun waktu tertentu. Karena data yang dipergunakan adalah data bulanan maka kinerja manajemen juga merupakan kinerja bulanan, triwulanan atau tahunan. (Yuli Orniati,2008).

Ricardson (2001) mengemukakan tentang metode penilaian kinerja manajemen koperasi simpan pinjam yang efektif, dimana manajemen koperasi dijabarkan dalam setiap kata atau huruf, yang disingkat dengan metode penilaian rasio PEARLS. PEARLS dianggap dapat memberikan perangkat standar yang lebih pasti dan alat manajemen yang lebih efektif yang sangat penting dan menentukan bagi keberhasilan dan daya tahan koperasi kredit. Rasio-rasio ini dapat digunakan sebagai alat penting bagi berbagai pihak yang bersangkutan, seperti koperasi, pengurus, pemerintah 
dan sebagainya untuk melakukan monitoring, membuat perencanaan, menetapkan standar-standar, peringkatan, fasilitas bagi pengawasan dalam koperasi.

Setiap huruf dari PEARLS mengukur bagian-bagian kunci dari kegiatan koperasi-koperasi: Protection, Effective Financial Structure, Asset Quality, Rate of Return and Costs, Liquidity dan Sign of Growth.

Tabel 1. Kelompok Rasio Protection dari PEARLS

\begin{tabular}{lc}
\multicolumn{1}{c}{ P $=$ Protection Indicators } & $\begin{array}{c}\text { Standars of } \\
\text { Excellence }\end{array}$ \\
\hline P1. Allowance for Loan Losses / Delinquency > 12 months & $100 \%$ \\
P2. Net Allowance for loan Losses / Delinquency of 1-12 months & $35 \%$ \\
P3. Total Write-off of Delinquent Loans > 12 months & $100 \%$ \\
P4. Annual Loan Write-offs/Average Loan Portfolio & Minimal \\
P5. Accumulated Loan Recoveries/Accumulated Loan Write- offs & $100 \%$ \\
P6. Solvency (Net Value of Assets/Total Shares and Deposits) & $>=110 \%$ \\
Sumber: World Council of Credit Unions,Inc.20oo &
\end{tabular}

Kelompok Rasio pertama adalah $\mathrm{P}$ atau Pretection (Perlindungan), yang terdiri dari enam rasio (Tabel 1 ). Rasio $\mathrm{P} 1$ adalah untuk mengukur kecukupan cadangan kerugian piutang dibandingkan semua piutang macet $>12$ bulan. Rasio P2 adalah untuk mengukur kecukupan cadangan kerugian piutang setelah dikurangi cadangan yang digunakan untuk menutup piutang macet $>12$ bulan. Rasio $\mathrm{P}_{3}$ adalah untuk mengukur total penghapusan piutang macet $>12$ bulan. Rasio $\mathrm{P}_{4}$ adalah untuk mengukur jumlah penghapusan piutang dari total piutang tahun ini. Catatan bahwa penghapusan piutang sebaiknya menggunakan buku pembantu dan tidak menampakan pada neraca. Rasio $\mathrm{P}_{5}$ adalah untuk mengukurt piutang sudah dihapus yang berhasil ditagih. Ini termasuk semua provisi tahun-tahun sebelumnya. Rasio P6 adalah untuk mengukur perlindungan terhadap simpanan dan saham anggotanya dalam peristiwa likuidasi aktiva dan hutang.

Kelompok rasio kedua adalah E atau Effective Financial Structure (Struktur Keuangan yang Efektif), yang mana mengukur komponen sisi perkiraan-perkiraan penting di dalam neraca. Indicator ini penting dalam mencapai keamanan, kesehatan,dan profitabilitas sekaligus menempatkan koperasi simpan pinjam pada pertumbuhan nyata yang agresif. Rasio ini terdiri dari sembilan Rasio (tabel 2). Rasio E1 adalah untuk mengukur prosentase total aktiva. Rasio E2 adalah untuk mengukur prosentase total aktiva yang dibiayai dengan investasi jangka pendek. RasioE3 adalah untuk mengukur prosentase total aktiva yang ditanamkan dalam jangka panjang. 
Rasio E4 adalah untuk mengukur prosentase total aktiva yang ditanamkan dengan investasi non-keuangan (supermarket, farmasi, gedung, pemerintah dan sebagainya). Rasio E5 adalah untuk mengukur prosentase total aktiva yang dibiayai dengan simpanan. Rasio E6 adalah untuk menmgukur prosentase total biaya aktiva dengan pinjaman luar (hutang obligasi diluar keuangan institusi kredit lainnya). Rasio E7 adalah untuk mengukur prosentase total aktiva dengan saham anggota. Rasio E8 adalah untuk mengukur prosentase total aktiva yang dibiayai dengan investasi institusi. Rasio E9 adalah untuk mengukur tingkat modal institusi setelah disesuaikan dengan tingkat cadangan risiko aktiva untuk mendapatkan standar P1 dan P2 dan menutup kerugian lainnya.

Tabel 2. Kelompok Rasio Effective Financial Structure dari PEARLS

\section{$\mathrm{E}=$ Effective Financial Structure Indicators $\quad$ Standars of Excellence}

E1. Net Loans / Total Assets $70 \%-80 \%$

E2. Liquid Investments/Total Assets

Maximum 20\%

E3. Financial Investments/Total Assets

Maksimum 10\%

E4. Non-Financial Investments/Total Assets

o\%

E5. Savings Deposits/Total Assets

$70 \%-80 \%$

E6. External Credit/Total Asset

Maksimum $5 \%$

E7. Member Share Capital/Total Assets

$10 \%-20 \%$

E8. Institutional Capital/Total Assets

Minimum 10\%

E9. Net Institutional Capital/Total Assets

Same as E8

Sumber: World Council of Credit Unions Inc., 2000

Kelompok Rasio ketiga adalah A atau Asset Quality (kualitas Aktiva), yang mana mengukur aktiva tidak produktif yang berdampak negatif terhadap profitabilitas dan solvabilitas yaitu piutang menunggak, aktiva tidak produktif dan biaya aktiva tidak produktif. Rasio ini terdiri dari tiga rasio (Tabel 3). Rasio A1 adalah untuk mengukur total prosentase piutang menunggak dengan kriteria saldo piutang menunggak yang belum dilunasi sebagai pengganti akumulasi pembayaran piutang menunggak. Rasio A2 adalah untuk mengukur prosentase total pendapatan aktiva tidak produktif. Rasio A3 adalah untuk mengukur prosentase aktiva tidak produktif yang dibiayai dengan modal institusi, modal transitory dan hutang tanpa bunga. 
Tabel 3. Kelompok Rasio Asset Quality dari PEARLS

\begin{tabular}{ll}
\hline \multicolumn{1}{|c|}{ A =Asset Quality } & Standard s of Excellence \\
\hline Ar Total Loan Delinquency/Gross Loan Portfolio & Maximum $5 \%$ \\
A2 Non-earning assets/Total assets & Maximum $5 \%$ \\
A3 Outstanding balance of delinquent & Goal is $<$ or $=5 \%$; \\
loans > 30 days/Total loans $\left({ }^{*}\right)$ & Maximum $10 \%$ of outstanding \\
& loans
\end{tabular}

$\left(^{*}\right)$ Note that standards of excellence required of a model credit union is $15 \%$; minimum standard for prudential purposes is $10 \%$

Sumber: World Council of Credit Unions, Inc.20oo

Kelompok Rasio Keempat adalah $\mathrm{R}$ atau Rate of Return and Cost (Tingkat pengembalian dan biaya), yang mana mengukur rata-rata pendapatan masing-masing aktiva produktif pada neraca dan mengukur rata-rata penghasilan (biaya) masing-masing pinjaman dan perkiraan modal. Penghasilan perputaran investasi yang sebenarnya dan tidak hanya khusus "spread analysis" penghasilan yang diperhitungkan berdasarkan rerata aktiva. The corresponding yields menunjukkan apakah koperasi kredit laba dan membayar bunga (market rate) atas aktiva, hutang dan modal. Rasio ini terdiri dari 12 rasio (Tabel 4 ).

Tabel 4. Kelompok Rasio Rate of Return \& cost dari PEARLS $\mathbf{R}=$ Rates of Return \& Cost

Standard s of Excellence

R1. Net Loan Income/Average Net Loan Portfolio

R2, Total Liquid Invesments Income/Average liquid investments

R3. Total Financial Investment Income/Average financial investments

R4. Total Non-Financial Investment Income/Average Non-financial investments

R5. Total Interest cost on Saving Deposits/Average saving deposit

R6. Total Interest cost on External Credit/Average Member shares

R7. Total interst (devidend) Cost on

Shares/Average Member Shares

R8. Total Grow Income Margin/Average Total Assets

R9. Total Operating Expenses/Average Total Assets

R1o. Total Loan Loss Provision Expense/Average Total Assets

R11. Non-earning Income or Expense/Average total Assets

R12. Net Income /Average Total Asset

Sumber: World Council of Credit Unions, Inc.20oo
Entrepreneurial Rate

Market Rates

Market Rates

$>\mathrm{R}_{1}$

Market rates > Inflation

Market rates

Market rates $>=\mathrm{R}_{5}$

Variable-linked to R9, R11,R12

5\%

Dependent on deliquent LOans

minimal

Linked to E9 
Rasio R1 adalah untuk mengukur piutang pendapatan. Rasio R2 adalah untuk mengukur penghasilan atas semua investasi jangka pendek (deposito bank dan lain-lain). Rasio $\mathrm{R}_{3}$ adalah untuk mengukur penghasilan atas semua investasi jangka panjang (deposito tetap,saham,surat-surat berharga, dan lain-lain). Rasio $\mathrm{R}_{4}$ adalah untuk mengukur hasil dari investasi non keuangan yang tidak dikategorikan dalam R1 dan R2, misalnya pendapatan dari supermarket, farmasi,persewaan tanah dan gedung pemerintah. Rasio R5 adalah untuk mengukur biaya simpan pinjam. Rasio R6 adalah untuk mengukur hasil (biaya) dari semua dana pinjam. Rasio $\mathrm{R}_{7}$ adalah untuk mengukur hasil (biaya) saham anggota. Rasio R8 adalah untuk mengukur jasa pendapatan lain lain sebagai prosentase dari total pendapatan. Rasio R9 adalah untuk mengukur pendapatan lain-lain sebagai prosentase dari total pendapatan.Rasio Rio adalah untuk mengukur biaya yang berhubungan dengan pengelolaan aktiva koperasi simpan pinjam. Biaya ini digunakan untuk mengukur prosentase total aktiva dan menunjukkan efisiensi atau tidaknya cara kerja organisasai. Rasio Rı adalah untuk mengukur biaya kerugian aktiva beresiko seperti piutang yang menunggak atau piutang tak tertagih. Biaya ini berbeda dengan biaya operasional lainnya sebaiknya dipisahkan untuk meningkatkan efektivitas kebijakan dan prosedur pengumpulan piutang koperasi simpan pinjam. Rasio R12 adalah untuk mengukur jumlah pendapatan dan biaya lain-lain. Khususnya bagian ini tidak penting jika koperasi koperasi kredit mengkhususkan pada tingkat keuangan lanjutan.

Tabel 5. Kelompok liquidity dari PEARLS

\section{$\mathrm{L}=$ Liquidity $\quad$ Standard s of} Excellence

L1. ST Investments + Liquid Assets - ST Minimum $15 \%$

Payable/Saving Deposits

L2. Liquidity Reserve / savings Deposits

L3. Non-earning Liquid Assets / Total Assets

$10 \%$

$<1 \%$

Sumber: World Council of Credit Unions,Inc.20oo

Kelompok rasio kelima adalah L atau Liquidity (likuiditas), yang mana menunjukkan apakah pengelolaan koperasi simpan pinjam efektif dapat juga menunjukkan permintaan pengembalian deposito dan persyaratan cadangan likuiditas lainnya. Kas yang menganggur juga mengukur pengangsuran aktiva tidak produktif yang tidak berpengaruh terhadap profitabilitas. Rasio ini terdiri dari tiga rasio (tabel 5). Rasio Li adalah untuk mengukur kemampuan persediaan kas lancar untuk memenuhi permintaan pengembalian deposito, seteleh pembayaran cadangan yang segera jatuh tempo <30 hari. Rasio L2 adalah untuk mengukur pemenuhan kewajiban 
kepada bank sentral atau persyaratan likuiditas cadangan deposito lainya. Rasio L3 adalah untuk mengukur prosentase total aktiva yang diinvestasikan pada aktiva lancar yang tidak produktif.

Tabel 6. Kelompok Signs of Growth dari PEARLS

\section{$\mathrm{S}=$ Signs of Growth Standard s of Excellence}

S1. Growth in Loans to Members

S2. Growth in Liquid Investments

S3. Growth in Financial Investments

S4. Growth in Non-Financial Investments

S5. Growth in savings Deposits

S6. Growth in External Credit

S7. Growth in Member Shares

S8. Growth in Institutional Capital

S9. Growth in Net Institutional Capital

S1o. Growth in Memberships

S11. Growth in Total Assets
Depedendet n E1

Depedendet n E2

Depedendet $n$ E3

Depedendet n $\mathrm{E}_{4}$

Depedendet $\mathbf{n}_{5}$

Depedendet n E6

Depedendet $\mathrm{n} \mathrm{E}_{7}$

Depedendet n E8

Depedendet n E9

$>12 \%$

$>$ Inflation

Sumber: World Council of Credit Unions, Inc.20oo

Kelompok Rasio keenam adalah S atau Sign of Growth, yang mana mengukur pertumbuhan masing-masing perkiraan penting dalam laporan keuangan dan juga pertumbuhan jumlah anggota. Dalam kondisi yang sedang inflasi, pertumbuhan ( setelah inflasi berkurang) adalah kunci untuk mempertahankan kelangsungan hidup koperasi kredit. Rasio ini terdiri dari sebelas rasio (tabel 6). Rasio Si adalah untuk mengukur pertumbuhan piutang per periode (bulan,triwulan dan tahun). Rasio S2 adalah untuk mengukur pertumbuhan investasi jangka pendek per periode. Rasi S3 adalah untuk mengukur pertumbuhan investasi keuangan per periode. Rasio $\mathrm{S}_{4}$ adalah untuk mengukur pertumbuhan investasi non keuangan per periode, Rasio $\mathrm{S}_{5}$ adalah untuk mengukur pertumbuhan simpanan deposito per perode. Rasio S6 adalah untuk mengukur pertumbuhan dana pinjaman per periode. Rasio $S_{7}$ adalah untuk mengukur pertumbuhan saham anggota per periode. Rasio S8 adalah untuk mengukur pertumbuhan modal institusi per periode. Rasio S9 adalah untuk mengukur pertumbuhan bersih modal institusi per periode. Rasio Sio adalah untuk mengukur pertumbuhan jumlah anggota. Rasio S11 adalah untuk mengukur pertumbuhan total aktiva per periode. 


\section{TUJUAN RASIO PEARLS}

Menurut Ricardson (2001) ada empat tujuan utama dari rasio PEARLS antara lain,

1. Sarana Manajemen eksekutif

Rasio PEARLS sangat cocok bagi manajer dalam mengidentifikasi masalahmasalah sederhana yang muncul dan mencari solusinya. Dengan menggunakan Rasio PEARLS, manajemen dapat dengan cepat dan akurat menunjukkan pos-pos yang bermasalah dan juga membuat penyesuaian penting sebelum masalah menjadi kritis.

2. Rumus dan Rasio yang standar

Dengan adanya rumus dan rasio penilaian yang standar yang dimiliki rasio PEARLS membuat atau menghilangkan bermacam-macam penilaian yang berbeda yang digunakan oleh koperasi simpan pinjam atau koperasi kredit.

3. Tujuan dan pembanding ranking

PEARLS dapat digunakan untuk membandingkan satu koperasi kredit dengan koperasi kredit lainnya, karena adanya penilaian standar yang obyektif dalam menilai suatu laporan keuangan koperasi simpan pinjam.

4. Fasilitas pengendalian bagi pihak pengawas.

Melalui pengendalian rasio PEARLS akan sangat berguna bagai pengawas koperasi dalam menjalankan tugasnya, karena PEARLS ini dapat digunakan untuk mengadakan penilaian atau triwulan atau bulanan pada semua pos kunci koperasi simpan pinjam.

Dalam memonitor kinerja koperasi, yang paling penting dan berharga adalah penggunaan sistem PEARLS dirancang sebagai alat manajemen. PEARLS adalah lebih dari sekedar identifikasi masalah-masalah, PEARLS membantu manajer-manajer koperasi kredit menemukan pemecahanpemecahan yang sangat berarti bagi kelemahn-kelemahan serius dari kelembagaan. Manajer mampu secara cepat dan akurat menunjuk wilayahwilayah kesulitas dan membuat penyesuaian-penyesuaian yang dilakukan sebelum masalahnya menjadi serius. PEARLS bertindak sebagai sistem peringatan dini yang menggerak-kembangkan informasi manajemen yang berharga bagi rencana strategis (RENSTRA) waktu mendatang. Rasio -rasio keuangan dan rumus-rumus yang distandarkan adalah untuk meniadakan kriteria yang bebeda-beda yang digunakan oleh koperasi kredit sekarang ini dalam menilai kegiatan-kegiatan mereka.

PEARLS adalah sistem monitoring kinerja keuangan yang dirancang untuk menawarkan bimbingan manajemen untuk Koperasi simpan Pinjam atau lembaga keuangan lainnya. PEARLS juga merupakan alat pengawasan 
untuk regulator.PEARLS dapat digunakan untuk membandingkan dan pemeringkat koperasi-koperasi simpan pinjam, yang dapat memberikan perbandingan antar lembaga di satu negara atau di seluruh negara.

PEARLS adalah seperangkat rasio keuangan atau indikator yang membantu untuk standarisasi terminologi antar lembaga. Secara total, ada 44 indikator keuangan kuantitatif yang memfasilitasi integral dari kondisi keuangan dari koperasi simpan pinjam atau lembaga keuangan lainnya. Tujuan berbagai indikator tersebut adalah untuk menggambarkan bagaimana perubahan dalam satu rasio memiliki konsekuensi bagi indikator indikator yang lainnya.

Setiap indikator memiliki prinsip kehati-hatian atau tujuan terkait. Tujuan target, atau standar rasio untuk masing-masing indikator diajukan oleh Dewan Dunia Koperasi Kredit (WOCCU) berdasarkan pengalaman kerja di lapangan untuk memperkuat dan memodernisasi koperasi simpan pinjam berbasis mempromosikan pertumbuhan. Nasabah atau anggota dapat memiliki keyakinan bahwa koperasi simpan pinjam memenuhi standar keunggulan yang aman dan sehat.

PEARLS merupakan suatu alat manajemen untuk koperasi simpan pinjam, juga dapat digunakan sebagai alat pengawasan oleh regulator. Sebagai alat manajemen, PEARLS memberikan sinyal permasalahan untuk manajer sebelum permasalahan tersebut menjadi merugikan. Untuk dewan direksi, PEARLS menyediakan alat untuk memantau kemajuan kinerja manajemen keuangan. Untuk regulator, PEARLS menawarkan indikator dan standar untuk mengawasi kinerja koperasi simpan pinjam. 
Tabel 7 di bawah ini menunjukkan rasio kunci dan target sasaran yang WOCCU telah dipilih sebagai standar minimum untuk mengukur kinerja koperasi kredit.

\section{Tabel 7. Minimum Standards}

\begin{tabular}{|c|c|}
\hline Indicator & Standard (Target or Goal) \\
\hline \multicolumn{2}{|l|}{ Protection } \\
\hline $\begin{array}{l}\text { Loan loss provision for loans delinquent }>12 \\
\text { months/Outstanding balance of these loans }\end{array}$ & $100 \%$ \\
\hline $\begin{array}{l}\text { Loan loss provision for loans delinquent }<12 \\
\text { months/Outstanding balance of these loans }\end{array}$ & $\begin{array}{l}\text { Minimum of } 35 \% \text { of delinquent loans from } 2 \\
\text { to } 12 \text { months }\end{array}$ \\
\hline \multicolumn{2}{|l|}{ Effective Financial Structure } \\
\hline Assets: Net loans/Total assets & 60 to $80 \%$ (country specific) \\
\hline Liquid investments/Total assets & Maximum $=20 \%$ \\
\hline Fixed (unproductive) assets/Total assets & Maximum = 5\% \\
\hline $\begin{array}{l}\text { Liabilities: Savings \& deposits (excluding } \\
\text { shares)/Total assets }\end{array}$ & Country specific target 70 to $80 \%$ \\
\hline External borrowing/Total assets & Minimised with a goal toward $0 \%$ \\
\hline $\begin{array}{l}\text { Capital: Reserves \& retained earnings/Total } \\
\text { assets }\end{array}$ & Minimum of $8 \%$ of total assets \\
\hline Share Mix: Withdrawable shares/Total assets & Country specific \\
\hline \multicolumn{2}{|l|}{ Asset Quality } \\
\hline $\begin{array}{l}\text { Outstanding balance of delinquent loans }> \\
30 \text { days/Total loans }\left({ }^{*}\right)\end{array}$ & $\begin{array}{l}\text { Goal is }<\text { or }=5 \% \text {; } \\
\text { Maximum } 10 \% \text { of outstanding loans }\end{array}$ \\
\hline Non-earning assets/Total assets $(*)$ & Maximum of $7 \%$ \\
\hline \multicolumn{2}{|l|}{ Rates of Return \& Costs } \\
\hline Operating expenses/Average assets $\left({ }^{*}\right)$ & $<$ or $=10 \%$ \\
\hline Net income/Average assets & Sufficient to maintain capital ratio of $>8 \%$ \\
\hline Return to members on share & > inflation rate \\
\hline \multicolumn{2}{|l|}{ Liquidity } \\
\hline $\begin{array}{l}\text { Liquidity Reserve/Withdrawable savings \& } \\
\text { deposits }\end{array}$ & $10 \%$ minimum \\
\hline \multicolumn{2}{|l|}{ Signs of Growth } \\
\hline $\begin{array}{l}\text { Annual net change in total assets/Total } \\
\text { assets of previous year }\end{array}$ & $\begin{array}{l}\text { Country specific }>\text { or = population growth } \\
\text { rate }\end{array}$ \\
\hline $\begin{array}{l}\text { Annual net change in loans/Total loans of } \\
\text { previous year }\end{array}$ & Country specific $>$ or $=$ inflation rate \\
\hline $\begin{array}{l}\text { Annual net change in withdrawable shares, } \\
\text { savings and deposits/Total savings and } \\
\text { deposits }\end{array}$ & Country specific $>$ or $=$ inflation rate \\
\hline
\end{tabular}

$\left.{ }^{*}\right)$ Note that standards of excellence required of a model credit union is $15 \%$; minimum standard for prudential purposes is $10 \%$

Terdapat tiga perbedaan utama antara PEARLS dan CAMEL: Capital Adequacy, Asset Quality, Management, Earnings, Liquidity (Capital 
Adequacy, Kualitas Aset, Manajemen, Pendapatan, Likuiditas) sebagai sistem penilaian kinerja keuangan:

- PEARLS menggunakan indikator kuantitatif ketat sementara CAMEL menggunakan kuantitatif dan kualitatif; (misalnya Manajemen). PEARLS memberikan evaluasi obyektif kinerja keuangan dengan meninjau hasil indikator kuantitatif yang ketat.

- PEARLS mengevaluasi struktur keuangan neraca. Struktur keuangan memiliki efek langsung pada efisiensi dan profitabilitas dari sebuah lembaga keuangan. Sejak institusi keuangan lebih memaksimalkan aset produktif, kemungkinan institusi lebih memiliki peluang untuk menghasilkan laba.

- PEARLS merupakan ukuran tingkat pertumbuhan. Pemantauan pertumbuhan di wilayah yang berbeda tidak hanya memungkinkan lembaga untuk menilai tingkat.kepuasan di antara para anggota, tetapi juga membantu manajer untuk mempertahankan struktur keuangan yang efektif mengingat bahwa pertumbuhan secara langsung mempengaruhi struktur keuangan.

\section{KESIMPULAN}

PEARLS berarti menciptakan bahasa keuangan universal yang dapat dimengerti oleh semua manajer koperasi kredit. Selanjutnya, penggunaan sistem akuntansi yang distandarkan dalam kaitannya dengan indikatorindikator kinerja PEARLS melahirkan sebuah jenis informasi baru yang lengkap bagi pembandingan peringkat pada koperasi koperasi kredit. Sebelum ini adalah tidak mungkin untuk membandingkan koperasi kredit yang satu dengan yang lain, disebabkan karena kriteria dan format-format laporan yang berbeda-beda yang terdapat pada koperasi-koperasi kredit yang sedang berkembang. Salah satu aspek yang sangat penting dari rasiorasio PEARLS adalah objektitif, tidak ada indikator-indikator yang kwalitatif dan subyektif yang dimasukkan ke dalam pemberian peringkat tersebut. Sebagai tambahan dari kegunaanya sebagai alat manajemen, sistem PEARLS memberikan kerangka-kerangka pengawasan bagi tingkat organisasi lebih atas dan pemerintah. Badan-badan ini dapat menggunakan rasio-rasio keuangan yang dikembangkan oleh PEARLS untuk melakukan bulanan, kwartalan dan tahunan terhadap semua wilayah kunci dari kegiatankegiatan koperasi-koperasi kredit. 


\section{DAFTAR PUSTAKA}

Atmadja, P. 2006. "Model pemeringkatan koperasi: Instrumen Penilaian Hasil dan DeteksiKeperluan Pemberdayaan Koperasi”, dimuat dalam Jurnal Volume 4, Agustus 2006.

Richardson, S. 2001. PEARLS Monitoring System. MFI Version. World Council of Credit Union.

Ropke, Jochen. 2003. Ekonomi Koperasi Teori dan Manajemen. Jakarta: Salemba Empat.

Soedjono, Ibnoe. 2003. Hubungan Gerakan Koperasi dengan Pemerintah, Ditinjau dari Pandangan Internasional. Jakarta: LSP2I.

Soedjono, Ibnoe. 2003. Instrumen-Instrumen Pengembangan Koperasi. Jakarta: LSP2I.

Anonim. 2000. Model Law For Credit Unions. World Council Of Credit Unions, Inc.

Richard, S. dan S. Oma. 1980. How To Measures Managerial Performance. New York: Macmillan Publishing.

Orniati, Y. 2008. "Perbedaan Kinerja keuangan Lembaga Keungan Mikro yang Diukur dengan Rasio PEARLS sebelum dan sesudah Kenaikan BBM", dimuat dalam Jurnal Manajemen Gajayana, Vol. 5, No. 1, Juni 2008. 